\title{
Isolasi Bakteri Asam Laktat Berpotensi Probiotik Pada Dangke, Makanan Tradisional dari Susu Kerbau di Curio Kabupaten Enrekang
}

\author{
FATMAWATI NUR $^{1}$, HAFSAN $^{1}$, ANDI WAHDINIAR ${ }^{1}$ \\ ${ }^{1}$ Jurusan Biologi, Fakultas Sains dan Teknologi, UIN Alauddin Makassar \\ J1. Sultan Alauddin 36 Samata, Kab. Gowa 92113 \\ email: fatenurkhalik@yahoo.com
}

\begin{abstract}
This research is a preliminary study to explore potential probiotics of Lactic Acid Bacteria (LAB) in dangke, a traditional food from buffalo milk in Curio the district of Enrekang. Isolation of LAB performed using the selective medium de Man Rogosa Sharpe Agar. LAB will show clear zone on MRS medium after the addition of the indicator in the form of $\mathrm{CaCO} 3$ and incubated for 24 hours. Selection is done by observing the cell morphology and Gram staining. Further testing with the biochemical properties of sugar fermentation test. The results showed that lactic acid bacteria isolates obtained consists of two species of Lactobacillus plantarum and Lactobacillus fermentum.
\end{abstract}

Keywords: Buffalo milk, dangke, Lactic Acid Bacteria, probiotic

\section{PENDAHULUAN}

Definisi probiotik menurut FAO/WHO adalah mikroorganisme hidup yang bila diberikan dalam jumlah yang cukup memberikan manfaat kesehatan pada inangnya (Araya et al., 2002). Penelitian invitro dan invivo, pada hewan percobaan maupun pada manusia telah banyak dilakukan untuk mengeksplorasi peranan probiotik dalam pencegahan maupun pengobatan penyakit, misalnya diare (Guandalini et al., 2011), Inflammatory Bowel Disease (Rauch et al., 2012), Irritable Bowel Syndrome (Ringel et al., 2011; Ki et al., 2012), asma (Jan et al., 2011; Jang et al., 2012), alergi (Drago et al., 2011; Wang et al., 2012), obesitas (Luoto et al., 2010; Arora et al., 2012), diabetes tipe 2 (Ejtahed et al., 2012; Andersson et al., 2010), kanker kolorektal (Kumar et al., 2012; Chen et al., 2011; Appleyard et al., 2011), laktosa intoleran (Ojetti et al., 2010; He et al., 2008), depresi (Arseneault et al., 2011; Desbonnet et al., 2010; Bravo et al., 2011), osteoporosis (Yeo et al., 2010; Rodrigues et al., 2012), reduksi kadar kolesterol (Kumar et al., 2012; Wang et al., 2012), dan pengikatan ion logam berat (Buda et al., 2013; Zhai et al., 2013).

Peranan probiotik terhadap pencegahan dan pengobatan beberapa penyakit telah dibuktikan, namun harganya masih relatif mahal. Oleh karena itu, pencarian sumber probiotik baru perlu dilakukan. Penelitian tentang isolasi bakteri berpotensi probiotik telah banyak dilakukakan diantaranya dari feces manusia (Tinrat et al., 2011), tinja bayi (Chiang et al., 2012), acar kyoto (Nonaka et al., 2008), kefir (Wang et al., 2012), kimchi (Won et al., 2011), dan sake (Kawamoto et al., 2011). Beberapa penelitian yang lain melakukan isolasi bakteri dari susu dan olahan susu, diantaranya dari Air Susu Ibu (Djide et al., 2008), susu sapi (Baruzzi et al., 2011), susu kerbau (Duary et al., 2011), susu kuda (Shi et al., 2012), susu fermentasi (Vizoso et al., 2007), dadih (Surono et al., 2011), dan dangke (Razak et al., 2009).

Dangke merupakan produk olahan susu kerbau atau susu sapi secara tradisional yang berasal dari Sulawesi Selatan khususnya kabupaten Enrekang. Dangke diolah dengan cara dipanaskan dengan api kecil sampai mendidih, kemudian ditambahkan koagulan berupa getah pepaya (papain) sehingga terjadi penggumpalan. Gumpalan tersebut dimasukkan ke dalam cetakan khusus yang terbuat dari tempurung kelapa sambil ditekan sehingga brothannya terpisah.

Tujuan dari penelitian ini adalah untuk mengetahui jenis Bakteri Asam Laktat (BAL) pada dangke, makanan tradisional dari susu kerbau di Curio Kabupaten Enrekang. Pada penelitian ini isolasi BAL dilakukan dengan 
menggunakan medium selektif de Man Rogosa Sharpe agar, pengamatan morfologi sel, pewarnaan Gram, pengujian sifat biokimia.

\section{METODE}

Preparasi Sampel Dangke. Sebanyak 10 gram dangke disuspensikan ke dalam larutan fisiologis $(\mathrm{NaCl} 0,9 \%)$ steril sebanyak $90 \mathrm{ml}$ dan dihomogenkan. Dari suspensi tersebut diambil $1 \mathrm{ml}$, dimasukkan ke dalam tabung pengencer yang berisi $9 \mathrm{ml}$ aquades steril, dihomogenkan menghasilkan pengenceran $10^{-}$ ${ }^{1}$ hingga pengenceran $10^{-3}$.

Isolasi dan Seleksi Bakteri Asam Laktat dari Dangke. Suspensi dangke diinokulasikan pada medium broth MRS Broth diinkubasi selama 24 jam pada suhu $37^{\circ} \mathrm{C}$. Kultur dari MRS Broth diinokulasikan pada medium MRSA lalu ditambahkan $\mathrm{CaCO}_{3} \quad 1 \%$, diinkubasi selama 48 jam. Koloni yang di sekitarnya terbentuk zona bening dimurnikan kembali pada medium MRSA dengan metode goresan sinambung lalu diinkubasi selama 24 - 48 jam. Penanaman dilakukan berulangulang pada medium dan kondisi yang sama hingga didapatkan koloni tunggal. Isolat murni tersebut lalu dipindahkan pada agar miring sebagai stok, disimpan di refrigerator pada suhu $4^{\circ} \mathrm{C}$.

Identifikasi Bakteri dengan Pewarnaan Gram dan Uji Biokimia. Gelas objek dibersihkan dengan alkohol 96\%, difiksasi di atas lampu spiritus, kemudian isolat aktif diambil secara aseptik dan diletakkan di atas gelas objek lalu diratakan. Difiksasi kembali di atas lampu spiritus. Setelah dingin diteteskan cat Gram A (kristal violet) 2-3 tetes selama 1 menit, dicuci dengan air mengalir dan dikeringkan di udara. Setelah itu ditetesi dengan Gram B (Iodium) selama 1 menit, dicuci dengan air mengalir dan dikeringkan. Kemudian ditetesi dengan Gram C (Alkohol 96\%) selama 30 detik, lalu dicuci dengan air mengalir dan dikeringkan di udara. Terakhir ditetesi dengan Gram D (Safranin) selama 45 detik, lalu dicuci dengan air mengalir dan kelebihan air dihilangkan dengan kertas serap. Pengamatan ini dilakukan dengan melihat bentuk dan warna sel dibawah mikroskop dengan pembesaran tertentu.
Identifikasi Bakteri dengan Pewarnaan Gram dan Uji Biokimia. Aktivitas biokimia atau metabolisme adalah berbagai reaksi kimia yang berlangsung dalam tubuh makhluk hidup untuk mempertahankan hidup.

1. Uji KIA. Isolat murni sebanyak satu ose digoreskan pada permukaan agar miring dan di inkubasi pada suhu $37^{\circ} \mathrm{C}$ selama 1 x 24 jam.

2. Uji Motility. Isolat murni sebanyak satu ose ditusuk hingga pertengahan medium untuk melihat sifat motil dari mikroba tersebut dan di inkubasi pada suhu $37^{\circ} \mathrm{C}$ selama 1 x 24 jam.

3. Uji Metil Red. Isolat murni diambil sebanyak satu ose dimasukkan kedalam medium dan di homogenkan setelah itu di inkubasi pada suhu $37^{\circ} \mathrm{C}$ selama $1 \times 24$ jam dan ditambahkan metil red.

4. Uji Voges Proskauer. Isolat murni diambil sebanyak satu ose dimasukkan kedalam medium dan di homogenkan. Di inkubasi pada suhu $37^{\circ} \mathrm{C}$ selama $1 \times 24$ jam kemudian di tambahkan pereaksi alfanaftol dan $\mathrm{KOH}$.

5. Uji Citrat. Isolat murni sebanyak satu ose digoreskan pada medium agar miring untuk uji citrat dan di inkubasi pada suhu $37^{\circ} \mathrm{C}$ selama $1 \times 24$ jam.

6. Uji Urea. Isolat murni sebanyak satu ose digoreskan pada medium agar miring untuk uji urea dan di inkubasi pada suhu $37^{\circ} \mathrm{C}$ selama $1 \times 24$ jam.

7. Uji Karbohidrat. Pada uji karbohidrat ini terdiri dari beberapa medium yaitu glukosa, lactosa, sukrosa, maltosa, manitol dan malonat. Pada setiap medium dimasukkan isolat murni sebanyak satu ose dan di homogenkan lalu diinkubasi pada suhu $37^{\circ} \mathrm{C}$ selama $1 \times 24$ jam.

8. Uji Katalase. Isolat murni diletakkan di atas gelas objek kemudian di tetesi dengan $\mathrm{H}_{2} \mathrm{O}_{2}$, diamati ada tidaknya gelembung gas yang dihasilkan.

\section{HASIL}

Isolasi dan Seleksi Bakteri Asam Laktat dari Dangke. Terdapat tiga isolat yang diperoleh dari dangke susu kerbau yang tumbuh pada medium MRSA $+\mathrm{CaCO}_{3}$ selama 
1x24 jam pada suhu $37^{\circ} \mathrm{C}$ memiliki morfologi koloni yang berbeda meliputi bentuk, tepi, elevasi dan warna.

Identifikasi Bakteri dengan Pewarnaan Gram dan Uji Biokimia. Dua isolat terpilih selanjutnya diamati sifat Gram dan aktivitas biokimianya untuk kepentingan karakterisasi dan identifikasi.

Tabel 1. Karakterisasi dan Identifikasi Bakteri Asam Laktat

Uji Biokimia

Isolat Bakteri

A B

Pewarnaan Gram

Basil Gram Positif

Basil Gram Positif

\begin{tabular}{lcc}
\hline Katalase & - & $\mathrm{A} / \mathrm{A},-/-$ \\
\hline KIA & $\mathrm{A} / \mathrm{A},-/-$ & - \\
\hline Urea & - & - \\
\hline S. Citrat & - & - \\
\hline LIA & - & $-/-$ \\
\hline MIO & $-/ /$ & + \\
\hline Glukosa & + & - \\
\hline Laktosa & + & + \\
\hline Sukrosa & + & + \\
\hline Maltosa & + & - \\
\hline Manitol & + & Lactobacillus fermentum \\
\hline Malonat & - & \\
\hline Species & Lactobacillus plantarum &
\end{tabular}

\section{PEMBAHASAN}

Isolasi dan Seleksi Bakteri Asam Laktat dari Dangke. Morfologi koloni yang berbeda yang tumbuh pada medium MRSA $+\mathrm{CaCO}_{3}$ selama 1 x 24 jam pada suhu $37^{\circ} \mathrm{C}$ menjadi dasar atas asusmsi bahwa ketiga isolat tersebut adalah jenis bakteri yang berbeda. Setelah dilakukan pemurnian atas ketiga isolat dan dilakukan skrining dengan menggunakan medium MRSA yang ditambahkan $1 \% \mathrm{CaCO} 3$ sebagai medium yang digunakan untuk menyeleksi bakteri asam laktat, dua isolat memperlihatkan zona bening di sekitar koloninya akibat dihasilkannya asam laktat yang bereaksi dengan $\mathrm{CaCO}_{3}$ membentuk Calactat yang larut dalam medium (Djide et al., 2008).

Dua isolat terpilih masing-masing isolat $\mathrm{A}$ dan B. Isolat A memiliki koloni kecil, sedang berbentuk bulat, elevasi cembung, tepi rata, permukaan berkilau, warna putih susu. Sedangkan isolat $\mathrm{B}$ menunjukkan morfologi koloni yang berbeda dengan isolat $\mathrm{A}$, yaitu koloni sedang hinga besar dan bulat. tepi rata, permukaan berkilau, warna putih susu.
Perbedaannya dengan isolat A terletak pada ukuran koloni yang lebih besar.

Identifikasi Bakteri dengan Pewarnaan Gram dan Uji Biokimia. Sifat Gram dan aktivitas biokimia pada tabel 1 yang dicocokkan dengan Bergey's Manual of Determinative Bacteriology menunjukkan bahwa isolat A dan B merupakan kelompok bakteri asam laktat yang teridentifikasi sebagai Lactobacillus plantarum dan Lactobacillus fermentum.

L. plantarum merupakan bakteri gram positif berbentuk basil $(0,5-1,5 \mathrm{~s} / \mathrm{d} 1,0-10 \mu \mathrm{m})$ serta tidak bergerak (non motil) yang terdapat secara berpasangan atau rantai pendek. Bakteri ini memiliki sifat katalase negatif, aerob atau fakultatif anaerob, mampu mencairkan gelatin, cepat mencerna protein, tidak mereduksi nitrat, dan toleran terhadap asam. Koloni berukuran 2-3 mm, cembung, berwarna putih dan tidak tembus cahaya. Bakteri ini mampu merombak senyawa kompleks menjadi senyawa yang lebih sederhana dengan hasil akhir yaitu asam laktat. 
L. fermentum termasuk dalam golongan Gram positif dengan sel basil nonmotil, ukuran sel 0,5-0,9 $\mu \mathrm{m}$, anaerob fakultatif, jarang dijumpai yang patogenik, serta dapat memfermentasi gula menjadi asam laktat, tahan pada kadar asam tinggi $(\mathrm{pH} 4-$ $5,5)$, tidak tumbuh pada $\mathrm{pH}$ di atas 6 .

\section{KESIMPULAN}

Penelitian ini menunjukkan bahwa isolat bakteri asam laktat yang diperoleh terdiri dari dua spesies yaitu Lactobacillus plantarum dan Lactobacillus fermentum, dan keduanya bisa bertahan hidup pada $\mathrm{pH} 2$. Isolat $L$. fermentum dan $L$. plantarum pada dangke yang berasal dari susu kerbau menunjukkan potensi sebagai calon bakteri probiotik.

\section{DAFTAR PUSTAKA}

Andersson U, Bränning C, Ahrné S, Molin G, Alenfall J, Onning G, Nyman M, Holm C. 2010. Probiotics Lower Plasma Glucose in The High-Fat Fed C57BL/6J Mouse. Benef Microbes. vol 1(2):189-96.

Appleyard CB, Cruz ML, Isidro AA, Arthur JC, Jobin C, De Simone C. 2011. Pretreatment with The Probiotic VSL\#3 Delays Transition from Inflammation to dysplasia in a Rat Model of ColitisAssociated Cancer. Am $J$ Physiol Gastrointest Liver Physiol. vol 301(6):1004-13.

Araya M, Morelli L, Reid G, Sanders ME, Stanton C. 2002. Report of a Joint FAO/WHO Working Group on Drafting Guidelines for the Evaluation of Probiotics in Food, London Ontario, Canada.

Arora T, Anastasovska J, Gibson G, Tuohy K, Sharma RK, Bell J, Frost G. 2012. Effect of Lactobacillus acidophilus NCDC 13 Supplementation on the Progression Of Obesity in diet-Induced Obese Mice. $\mathrm{Br} J$ Nutr. vol 31:1-8.

Arseneault BJ, Rondeau I, Gilbert K, Girard SA, Tompkins TA, Godbout R, Rousseau G. 2011. Combination of Lactobacillus helveticus R0052 and Bifidobacterium longum R0175 Reduces Post-Myocardial Infarction Depression Symptoms and
Restores Intestinal Permeability in a Rat Model. Br J Nutr. vol 21: 1-7.

Baruzzi F, Poltronieri P, Quero GM, Morea M, Morelli L. 2011. An in vitro Protocol for Direct Isolation of Potential Probiotic Lactobacilli from Raw Bovine Milk and Traditional Fermented Milks. Appl Microbiol Biotechnol. vol 90(1): 331-42.

Bravo JA, Forsythe P, Chew MV, Escaravage E, Savignac HM, Dinan TG, Bienenstock J, Cryana JF. 2011. Ingestion of Lactobacillus Strain Regulates Emotional Behavior and Central GABA Receptor Expression in a Mouse Via The Vagus Nerve. Proc Natl Acad Sci USA. vol 108(38): 16050-16055.

Buda B, Dylus E, Górska-Frączek S, Brzozowska E, Gamian A. 2013. Biological Properties of Lactobacillus Surface Proteins. Postepy Hig Med Dosw. vol 67: 229-237.

Chen CC, Lin WC, Kong MS, Shi HN, Walker WA, Lin CY, Huang CT, Lin YC, Jung SM, Lin TY. 2011. Oral Inoculation of Probiotics Lactobacillus Acidophilus NCFM Suppresses Tumour Growth Both in Segmental Orthotopic Colon Cancer and Extra-Intestinal Tissue. Br J Nutr. vol 30: $1-12$.

Chiang SS and Pan TM. 2012. Beneficial Effects of Lactobacillus paracasei subsp. paracasei NTU 101 and Its Fermented Products. Applied Microbiology and Biotechnology. vol 93(3): 903-16.

Desbonnet L, Garrett L, Clarke G, Kiely B, Cryan JF, Dinan TG. Effects of The Probiotic 2010. Bifidobacterium infantis in The Maternal Separation Model of Depression. Neuroscience. vol 170(4): 1179-88.

Djide MN dan Wahyudin E. 2008. Isolasi Bakteri Asam Laktat dari Air Susu Ibu, dan Potensinya dalam Penurunan Kadar Kolesterol Secara In Vitro. Majalah Farmasi dan Farmakologi. vol 12(3): 7378.

Drago L, Iemoli E, Rodighiero V, Nicola L, De Vecchi E, Piconi S. 2011. Effects of Lactobacillus salivarius LS01 (DSM 22775) Treatment on Adult Atopic 
Dermatitis: A Randomized PlaceboControlled Study. Int J Immunopathol Pharmacol. vol 24(4): 1037-48.

Duary RK, Rajput YS, Batish VK, Grover S. 2011. Assessing The Adhesion of Putative Indigenous Probiotic Lactobacilli to Human Colonic Epithelial Cells. Indian J Med Res. vol 134(5): 664-671.

Ejtahed HS, Mohtadi NJ, Homayouni RA, Niafar M, Asghari-Jafarabadi M, Mofid V. 2012. Probiotic Yogurt Improves Antioxidant Status in Type 2 Diabetic Patients. Nutrition. vol 28(5): 539-43.

Guandalini and Stefano MD. 2011. Probiotics for Prevention and Treatment of Diarrhea. Journal of Clinical Gastroenterology. vol 45: 149-153.

He T, Priebe MG, Zhong Y, Huang C, Harmsen HJ, Raangs GC, Antoine JM, Welling GW, Vonk RJ. 2008. Effects of Yogurt and Bifidobacteria Supplementation on The Colonic Microbiota in Lactose-Intolerant Subjects. J Appl Microbiol. vol 104(2): 595-604.

Jan RL, Yeh KC, Hsieh MH, Lin YL, Kao HF, Li PH, Chang YS, Wang JY. 2011. Lactobacillus gasseri Suppresses Th17 Pro-Inflammatory Response and Attenuates Allergen-Induced Airway Inflammation in A Mouse Model of Allergic Asthma. Br J Nutr. vol 14:1-10.

Jang SO, Kim HJ, Kim YJ, Kang MJ, Kwon JW, Seo JH, Kim HY, Kim BJ, Yu J, Hong SJ. 2012. Asthma Prevention by Lactobacillus Rhamnosus in a Mouse Model is Associated With CD4+CD25+Foxp3+ T Cells. Allergy Asthma Immunol Res. vol 4(3): 150-156.

Kawamoto S, Kaneoke M, Ohkouchi K, Amano Y, Takaoka Y, Kume K, Aki T, Yamashita S, Watanabe K, Kadowaki M, Hirata D, Ono K. 2011. Sake Lees Fermented with Lactic Acid Bacteria Prevents Allergic Rhinitis-Like Symptoms and IgE-Mediumted Basophil Degranulation. Biosci. Biotechnol. Biochem. vol 75(1): 140-144.

Ki CB, Mun JS, Hwan CC, Song ID, Woong LH, Joon KH, Hyuk J, Kyung CS, Kim K, Chung WS, Seo JG. 2012. The Effect of A
Multispecies Probiotic Mixture on The Symptoms and Fecal Microbiota in Diarrhea-Dominant Irritable Bowel Syndrome: A Randomized, Double-Blind, Placebo-Controlled Trial. $J$ Clin Gastroenterol. vol 46(3): 220-7.

Kumar M, Nagpal R, Hemalatha R, Verma V, Kumar A, Chakraborty C, Singh B, Marotta F, Jain S, Yadav H. 2012. Cholesterol-Lowering Probiotics as Potential Biotherapeutics for Metabolic Diseases. Exp Diabetes Res. vol 2012: 902-917.

Kumar RS, Kanmani P, Yuvaraj N, Paari KA, Pattukumar V, Thirunavukkarasu C, Arul V. 2012. Lactobacillus plantarum AS1 Isolated from South Indian Fermented Food Kallappam Suppress 1,2-dimethyl hydrazine (DMH)-Induced Colorectal Cancer in Male Wistar Rats. Appl Biochem Biotechnol. vol 166(3): 620-31.

Luoto R, Kalliomäki M, Laitinen K, Isolauri E. 2010. The Impact of Perinatal Probiotic Intervention on The Development of Overweight and Obesity: Follow-Up Study from Birth to 10 Years. Int J Obes. vol 34(10): 1531-1537.

Nonaka Y, Izumo T, Izumi F, Maekawa T, Shibata H, Nakano A, Kishi A, Akatani K, Kiso Y. 2008. Antiallergic Effects of Lactobacillus pentosus strain S-PT84 Mediumted by Modulation of Th1/Th2 Immunobalance and Induction of IL-10 Production. Int Arch Allergy Immunol. vol 145(3): 249-57.

Ojetti V, Gigante G, Gabrielli M, Ainora ME, Mannocci A, Lauritano EC, Gasbarrini G, Gasbarrini A. 2010. The Effect of Oral Supplementation with Lactobacillus reuteri or Tilactase in Lactose Intolerant Patients: Randomized Trial. Eur Rev Med Pharmacol Sci. vol 14(3): 163-70.

Pan DD, Zeng XQ, Yan YT. 2011. Characterisation of Lactobacillus fermentum SM-7 Isolated from koumiss, A Potential Probiotic Bacterium with Cholesterol-Lowering Effects. J Sci Food Agric. vol 91(3): 512-8.

Rauch M and Lynch S. 2012. The Potential for Probiotic Manipulation of The 
Gastrointestinal Microbiome. Curr Opin Biotechnol. vol 23(2): 192-201.

Razak AR, Patong AR, Harlim T, Djide MN, Haslia, Mahdalia. 2009. Produksi Senyawa Bakteriosin Secara Fermentasi Menggunakan Isolat BAL Enterococcus faecium DU55 dari Dangke. Indonesia Chemica Acta. vol 2(2): 1-9.

Ringel Y and Ringel-Kulka T. 2011. The Rationale and Clinical Effectiveness of Probiotics in Irritable Bowel Syndrome. $J$ Clin Gastroenterol. vol 45: 145-8.

Shi T, Nishiyama K, Nakamata K, Aryantini NPD, Mikumo D, Oda Y, Yamamoto Y, Mukai T, Sujaya IN, Urashima T, and Fukuda K. 2012. Isolation of Potential Probiotic Lactobacillus rhamnosus Strains from Traditional Fermented Mare Milk Produced in Sumbawa Island of Indonesia. Biosci. Biotechnol. Biochem. vol 76(10): 1879-1903.

Surono IS, Koestomo FP, Novitasari N, Zakaria FR, Yulianasari, Koesnandar. 2011. Novel Probiotic Enterococcus faecium IS-27526 Supplementation Increased Total Salivary Siga Level and Bodyweight of Pre-School Children: A Pilot Study. Anaerobe. vol 17(6): 496500.

Tinrat S, Saraya Sumam, and Chomnawang MT. 2011. Isolation and Characterization of Lactobacillus salivarius MTC 1026 as a Potential Probiotic. J. Gen. Appl. Microbiol. vol 57: 365-378

Vizoso PMG, Schuster T, Briviba K, Watzl B, Holzapfel WH, Franz CM. 2007.
Adhesive and Chemokine Stimulatory Properties of Potentially Probiotic Lactobacillus Strains. Journal Of Food Protection. vol 70(1): 125-34.

Wang HF, Tseng CY, Chang MH, Lin JA, Tsai FJ, Tsai $\mathrm{CH}$, Lu YC, Lai CH, Huang CY, Tsai CC. 2012. Anti-inflammatory Effects of Probiotic Lactobacillus paracasi on Ventricles of BALB/C Mice Treated with Ovalbumin. Chin J Physiol. vol 55(1): 3746.

Wang J, Zhang $\mathrm{H}$, Chen $\mathrm{X}$, Chen $\mathrm{Y}$, Menghebilige, Bao Q. 2012. Selection of Potential Probiotic Lactobacilli for Cholesterol-Lowering Properties and Their Effect on Cholesterol Metabolism in Rats Fed A High-Lipid Diet. J Dairy Sci. vol 95(4):1645-54

Won TJ, Kim B, Lim YT, Song DS, Park SY, Park ES, Lee DI, Hwang KW. 2011. Oral Administration of Lactobacillus strains from Kimchi Inhibits Atopic Dermatitis in NC/Nga Mice. J Appl Microbiol. vol 110(5): 1195-202.

Yeo SK and Liong MT. 2010. Angiotensin IConverting Enzyme Inhibitory Activity and Bioconversion of Isoflavones by Probiotics in Soymilk Supplemented with Prebiotics. Int J Food Sci Nutr. vol 61(2): 161-81.

Zhai Q, Wang G, Zhao J, Liu X, Tian F, Zhang H, and Chen W. 2013. Protective Effects of Lactobacillus plantarum CCFM8610 against Acute Cadmium Toxicity in Mice. Appl Environ Microbiol. vol 79(5): 15081515. 